\title{
REINTERPRETING THE "BODY" IN THE SECOND SEX
}

\section{Supakwadee Amatayakul ${ }^{1}$}

Simone de Beauvoir's The Second Sex is unarguably one of the most original books written in the twentieth century. Her dictum, "one is not born, but rather becomes, a woman," expresses a highly genuine account of how the female body is the product of profound social and historical forces. No feminist before de Beauvoir had analyzed ideas about the body in this way. However, in the later waves of feminism, when feminists began to upgrade that which was specifically feminine, de Beauvoir's account of woman's body and biology increasingly became a focus of criticism. Some critics have found that de Beauvoir's account is deterministic. Judith Okeley, for example, says: "Despite de Beauvoir's formal rejection of biological determinism, when the details of her arguments are closely examined it can be seen that she contradicts any claim that biological factors are irrelevant or arbitrary. Again and again she slips into biological determinism to explain the primary cause of women's subordination." Others have found that de Beauvoir's analysis of woman's body reflect a negative attitude, and thus have come to charge her with adopting a hostile, "masculinist," and "essentialist" stance towards women, and towards the female

\footnotetext{
${ }^{1}$ Lecturer, Department of Philosophy, Faculty of Arts, Chulalongkorn University, Thailand.

${ }^{2}$ Okeley, p. 90.
}

body in particular. $^{3}$ Admittedly, it is understandable why anyone would make such claims upon reading The Second Sex, for de Beauvoir does say that females are more enslaved to the species than males, that women are less transcendent than men, and that women are alienated from their bodies in the course of normal processes such as menstruation, pregnancy, and childbirth. It is true that the evidence for their accusations against de Beauvoir is not at all difficult to find. But are these accusations justifiable? In other words, while it cannot be denied that The Second Sex contains a number of negative remarks about woman's biology, do these remarks really constitute biological determinism? Are they really evidence for de Beauvoir's masculinist attitude towards women? Do these charges against her have a firm foundation?

At this point, it might be important that we address the question "what is biological determinism?" Margaret A. Simons defines "biological determinism" as the view which holds that human capacities are subject to

\footnotetext{
${ }^{3}$ See, for example, O'Brien, Mary. 1981. The politics of Reproduction. London: Routledge and Kegan Paul.; Evans, Mary. 1987. "Views of Women and men in the Work of Simone de Beauvoir." In Critical Essays on Simone de Beauvoir, edited by Elaine Marks, 172-84. Boston: G. K. Hall.
} 
deterministic biological laws, i.e. that biological properties determine human capacities. $^{4}$ Hence, Okeley's criticism quoted above, that de Beauvoir employs biological determinism to explain the primary cause of the subordination of women, means that in her view, de Beauvoir assumes that female characteristics are biological "givens," fixed by nature, so as to doom woman to eternal subordination to man.

In an attempt to reconcile apparent contradictions among de Beauvoir's claims about woman's body in The Second Sex, it is my intention to argue in this paper that she clearly rejects biological determinism, and also that her account is not masculinist, i.e. that she does not assume a masculine view in discussing the female body. I will divide my arguments into two major parts: in the first part, I will briefly analyze the overall structure of The Second Sex, and discuss in particular the structure and significant comments of the first three chapters. My purpose is to show that de Beauvoir is not committed to the negative views about the female body that she sometimes mentions. This will disprove both the biological determinist and the masculinist objections. In the second part, I will demonstrate how de Beauvoir conducts her discussion about the body on two different levels, following her claim that it is her intention to consider the body not as a thing, but as a situation. ${ }^{5}$ By doing so, I hope to show that if we put her comments in their proper context by considering the perspective from which she makes them, neither the charge of biological

\footnotetext{
${ }^{4}$ Simons, p. 246.

${ }^{5}$ De Beauvoir, p. 34.
}

determinism, nor that of masculinism, has a firm foundation.

\section{The Structure of The Second Sex}

First, it is important that we consider de Beauvoir's preliminary assumption in The Second Sex in order to obtain a clear view of her project. At the end of the introduction, she states:

Quite evidently this problem [woman's liberty] would be without significance if we were to believe that woman's destiny is inevitably determined by physiological, psychological, or economic forces. ${ }^{6}$

To begin with, it is apparent that de Beauvoir wrote the first three chapters in order to reject any form of determinism, be it biological, psychological, or economic. More will be said about this issue in the discussion of the initial three chapters. As for now, let us consider de Beauvoir's general framework:

Hence I shall discuss first of all the light in which woman is viewed by biology, psychoanalysis, and historical materialism. Next I shall try to show exactly how the concept of the 'truly feminine' has been fashioned -- why woman has been defined as the Other-- and what have been the consequences from man's point of view. Then from woman's point of view I shall describe the world in which women

\footnotetext{
${ }^{6}$ De Beauvoir, p. xxxv (emphasis added).
} 
must live; and thus we shall be able to envisage the difficulties in their way as, endeavouring to make their escape from the sphere hitherto assigned them, they aspire to full membership in the human race.

The Second Sex is divided into two major parts: Book $I$ and Book II. The initial three chapters on biology, psychoanalysis, and historical materialism, which constitute the "Destiny" part, preface the chapters in the "History" and "Myths" parts. Together these parts constitute Book $I$ called "Les Faits et Les Mythes" or "Facts and Myths," which precedes Book II entitled "L'Exprience Vcu" or "Lived Experience."8 By naming them thus, and also following her statement above, the two halves of the work suggest distinct yet interrelated levels of analysis, the first half emphasizing abstract constructs with which male thinkers have theorized about woman, the second what woman's experience under patriarchy has been like. This order, then, suggests a "top-down" approach to her discussion: a mode of analysis such that the myths and theories detailed in Book $I$ are to be regarded as part of the conceptual apparatus presupposed in the lived experience of women in Book II. ${ }^{9}$ Keeping this approach in mind, one obvious objection to the charge of masculinism against de Beauvoir becomes apparent. Due to the fact that the theories and myths detailed in Book I constitute part of the theoretical framework

\footnotetext{
${ }^{7}$ De Beauvoir, p. xxxv (emphasis added).

${ }^{8}$ For some reason, H.M. Parshley translated the title of Book II as "Woman's Life Today," which I think is inaccurate.

${ }^{9}$ Whitmarsh, p. 57.
}

of patriarchy, there is no reason for assuming that the negative remarks which are made about women and their experience are necessarily affirmed by de Beauvoir herself. This said, I will now proceed to discuss the structure and important remarks of the initial three chapters to further demonstrate that the charges of biological determinism as well as masculinism against de Beauvoir are groundless.

In order to consider woman in her "total situation," de Beauvoir provides us in the three initial chapters with a long list of "facts" which men have theorized about women, and concludes each of them with critical comments, detailing the inadequacies of each theoretical approach. From a broader perspective, it can also be seen that she rejects the claims of each chapter by using parts of the theories from the immediately following chapters, i.e. she rejects the data of biology by using parts of Freud's psychoanalysis, then rejects the Freudian explanation of women by using Marxism, which she again rejects because it perceives women and men merely as economic units. It can be inferred, then, that de Beauvoir is open to rejecting either part or all of the conceptual analyses of women given in Book I. For the sake of clarity, I will separately analyze de Beauvoir's position towards the ideas presented in the chapters on biology, psychoanalysis, and historical materialism, and synthesize her points of contention/ rejection where applicable.

De Beauvoir begins the chapter on biology with a highly controversial statement: "Woman? Very simple, say the fanciers of simple formulas: she is a womb, an ovary; 
she is female -- this word is sufficient to define her." ${ }^{10}$ These few ironic words have led critics to a misunderstanding that de Beauvoir subscribes to the traditional, masculinist view of woman merely as a reproductive vessel. ${ }^{11}$ In my opinion, this misinterpretation is a result of the failure to consider the fact that since much of the theoretical discussion in Book $I$ is the product of male theorizing about women, it will inevitably be subject to some criticism by de Beauvoir. Thus, it follows that when we encounter various apparently deterministic statements about woman's body in this chapter, we cannot thereby conclude that Beauvoir is uncritically accepting them. A few lines later in the same paragraph, she declares that these negative remarks cannot be identified as her own: "Females sluggish, eager, artful, stupid, callous, lustful, ferocious, abased -man projects them all at once upon woman." 12 As the chapter progresses, de Beauvoir begins to comment on the inadequacy of the theory about woman's biology:

Thus, admitting no a priori doctrine, no dubious theory, we are confronted by a fact for which we can offer no basis in the nature of things nor any explanation through observed data, and the significance of which we cannot comprehend $a$ priori. We can hope to grasp the significance of sexuality only by studying it in its concrete manifestations; and then perhaps the

${ }^{10}$ De Beauvoir, p. 3.

${ }^{11}$ Ehrmann, p. 91.

${ }^{12}$ De Beauvoir, p. 4 (emphasis added). meaning of the word female will stand revealed. ${ }^{13}$

Clearly, de Beauvoir is contending that the "biological facts" are not sufficient to explain woman's sexuality, and she thereby rejects them:

I deny that they establish for her a fixed and inevitable destiny. They are insufficient for setting up a hierarchy of the sexes; they fail to explain why woman is the Other; they do not condemn her to remain in this subordinate role for ever. ${ }^{14}$

At this point, one might ask, "if biology is insufficient in explaining woman's body, then what is?" In fact, de Beauvoir herself answers this question best:

It is not merely as a body, but rather as a body subject to taboos, to laws, that the subject is conscious of himself and attains fulfillment -- it is with reference to certain values that he evaluates himself. And, once again, it is not upon physiology that values can be based; rather, the facts of biology take on the values that the existent bestows upon them. ${ }^{15}$

De Beauvoir then concludes the chapter on biology by establishing that the significance of human biology and of the differences between the sexes can never be clarified

\footnotetext{
${ }^{13}$ De Beauvoir, p. 9.

${ }^{14}$ De Beauvoir, pp. 32-33.

${ }^{15}$ De Beauvoir, p. 36.
} 
apart from the ontological, economic, social, and psychological context. She also establishes that the biological data take on different significations in different historical situations. Up to this point, I think it is evident that any deterministic account of woman, especially that of biology, runs contrary to her own foundations since the whole point of de Beauvoir's analysis of woman is to appreciate the complexity of being feminine. Hence, "our task is to discover how the nature of woman has been affected throughout the course of history; we are concerned to find out what humanity has made of the human female." ${ }^{\text {.16 }} \mathrm{De}$ Beauvoir then proceeds to the next chapter to discuss woman's biology in the psychological context.

The account of woman's psychology presented in the chapter "The Psychoanalytic Point of View," as in the previous chapter, is eventually criticized by de Beauvoir. At first, she points out the positive aspect of psychoanalysis which lies in the view that "it is not the body-object described by biologists that actually exists, but the body as lived in by the subject. Woman is a female to the extent that she feels herself as such." This is precisely what de Beauvoir has argued in the first chapter, i.e. that biological features do not entirely determine woman's real, experienced situation; therefore, "it is not nature that defines woman."17

De Beauvoir criticizes the psychoanalytic theory in general, and Freud in particular, for its/his masculine basis in theorizing about woman's psychology: "Freud never

${ }^{16}$ De Beauvoir, p. 37.
${ }^{17}$ De Beauvoir, p. 38. showed much concern with the destiny of woman; it is clear that he simply adapted his account from that of the destiny of man, with slight modifications."18 Furthermore, she accuses Freud of biological determinism because he considers woman as being determined by her sexuality alone. She therefore launches the following critique in order to distinguish herself from Freud's position:

Woman can be defined by her consciousness of her own femininity no more satisfactorily than by saying that she is a female, for she acquires this consciousness under circumstances dependent upon the society of which she is a member. ${ }^{19}$

As already stated, de Beauvoir wishes to consider woman in her "total situation," and not from any single perspective. Psychoanalysis, she says, "fails to explain why woman is the Other" because it fails to consider that "a life is a relation to the world, and the individual defines himself by making his own choices through the world about him ... we must therefore turn towards the world to find answers for the questions we are concerned with." 20 Subsequently, de Beauvoir rejects psychoanalysis for its partiality and ahistoricity, specifically faulting the theory for its failure to explain, rather than merely assert, the supremacy of male over female as reflected in the sovereignty of the phallus: "for Freud himself admits that the prestige of the penis

\footnotetext{
${ }^{18}$ De Beauvoir, p. 39.

${ }^{19}$ De Beauvoir, p. 49.

${ }^{20}$ De Beauvoir, p. 49.
} 
is explained by the sovereignty of the father, and, ... he confesses that he is ignorant regarding the origin of male supremacy. ${ }^{21}$ Therefore:

We decline to accept the method of psychoanalysis, without rejecting en bloc the contributions of the science or denying the fertility of some of its insights. In the first place, we do not limit ourselves to regarding sexuality as something given. The insufficiency of this view is shown by the poverty of the resulting descriptions of the feminine libido ${ }^{22}$

Having detailed the inadequacies of the psychoanalytic point of view, de Beauvoir moves on to analyze woman in the economic and social context.

Again, de Beauvoir opens the third chapter by stating the significance of the historical materialism theory. She agrees with the concept that humanity is a historical reality, and not an animal species. It seems that de Beauvoir is also using the central idea of the theory of historical materialism to argue against biological determinism: "Human society is an antiphysis -- in a sense it is against nature; it does not passively submit to the presence of nature but rather takes over the control of nature on its own behalf." 23 Before discussing the details of the theory, de Beauvoir sums up the inadequacies of both the biological and psychological treatment of woman.

${ }^{21}$ De Beauvoir, p. 49.

${ }^{22}$ De Beauvoir, p. 49 (emphasis added).

${ }^{23}$ De Beauvoir, p. 53.
Thus woman could not be considered simply as a sexual organism, for among the biological traits, only those have importance that take on concrete value in action. Woman's awareness of herself is not defined exclusively by her sexuality: it reflects a situation that depends upon the economic organization of society, which in turn indicates what stage of technical evolution mankind has attained. ${ }^{24}$

However, when she summarizes the differences between the sexes, she says that the two biological traits that characterize woman are that her grasp upon the world is less "extended" than man's, and that she is more closely enslaved to the species. It is most likely that what de Beauvoir has in mind here are the various physiological differences she details in the chapter on biology, for example, the relatively smaller musculature of women to men, and the possession of fewer red blood corpuscles so that the gross muscular effort is lower. ${ }^{25}$

Do these and related comments suggest she is being "masculinist" in her view of the female body as her critics charge? I do not think so, although it is easy enough to see in her descriptions of woman the basis for the criticism that she is mixing biological "facts" with value judgments. ${ }^{26}$ Nevertheless, de Beauvoir is in fact not unaware that "factual" descriptions are insignificant in themselves and acquire meaning only by being placed in a

\footnotetext{
${ }^{24}$ De Beauvoir, p. 53.

${ }^{25}$ De Beauvoir, p. 34.

${ }^{26}$ L?on, p. 28.
} 
social/cultural context. As she notes directly after making the above-mentioned comments: "these facts take on different values according to the economic and social context. In human history, grasp upon the world has never been defined by the naked body ... on the contrary, technique may annul the muscular inequality of man and woman." ${ }^{27}$ As a consequence, although she acknowledges physical differences such as the relatively greater musculature of men over women, she most accurately points out that this difference in itself signifies nothing. As a matter of fact, she argues that the large part of human history has been concerned with the improvement of technology, the historical effect of which has been to negate all the advantages of brute strength. Thus, she is arguing precisely contrary to what she ought to be if she were in fact holding some form of biological determinism.

It is evident that in this chapter, where although de Beauvoir embraces the notion of humans as subject to historical material conditions, she maintains that the Marxist theory itself is inadequate to explain the concrete situation for human beings: "...in order to comprehend that situation we must look beyond the historical materialism that perceives in man and woman no more than economic units." 28 Hence, since de Beauvoir wants to reject any deterministic account of woman as she has already rejected what might be called "biological monism," she again states: "we reject for the same reasons both the sexual monism of Freud and the economic monism of Engels,"

\footnotetext{
${ }^{27}$ De Beauvoir, p. 53.

${ }^{28}$ De Beauvoir, p. 60.
}

because "unless they are integrated into the totality of human reality, sexuality and technology alone can explain nothing., ${ }^{, 29}$

From the discussions of the overall structure and the initial three chapters of The Second Sex above, we may conclude that de Beauvoir denies that any one set of given conditions, in this case, biological characteristics, could ever be fully determinative of feminine experience; rather, women's status and self-identity is constituted by the set of external, social conditions in which women find themselves. Therefore, if woman's self-awareness cannot be said to be determined by a natural sexual identity, then it becomes untenable to claim that de Beauvoir subscribes to some form of biological determinism.

\section{The Body as a "Situation"}

To begin with, what does de Beauvoir mean when she says: "if the body is not a thing, it is a situation" ? ${ }^{30}$ Briefly, this statement can be interpreted as her assertion that the physical capacities of either sex gain meaning only when placed in a cultural and historical context. I contend that if de Beauvoir takes seriously the notion that the body is itself a situation, as I believe she does, she must reject the idea of the body as a purely biological mechanism, contrary to her critics' charge.

The term "situation" appears frequently in The Second Sex, and has special

\footnotetext{
${ }^{29}$ De Beauvoir, p. 60.

${ }^{30}$ De Beauvoir, p. 34.
} 
significance in de Beauvoir's analysis of the body. In general, de Beauvoir uses "situation" to signify the specific historical and social contexts in which women find themselves to be the Other, that is, relegated to a subordinate status relative to men. In such occurrences, the word clearly signifies the set of social, economic, and material conditions that give rise to the psychological, subjective condition of being a woman. Significantly, de Beauvoir also chooses to analyze the concept of the body in terms of situation, the effect of which is to reconceive the body as a social construction, as opposed to a physical entity. In fact, we can find both senses of "body" being referred to in the chapter on biology where de Beauvoir asserts her preference for the constructivist conception of the body, in spite of her long discussion of the "alienating" aspects of female biological functions. She says: "it [woman's body] constitutes an essential element in her situation." And also "...the body being the instrument of our grasp upon the world, the world is bound to seem a very different thing when apprehended in one manner or another. ${ }^{31}$ We can see that de Beauvoir is here employing the notion of situation to explain the sense in which the biological statements about "body" are to be considered. She distinguishes between two different conceptions of "body": at one level, it may be said to signify the body conceived of as inert matter, or "a thing," as she terms it; at another level, it signifies how the physical body is experienced, given the social and economic conditions, and here her term is situation. The body conceived of on the first level is roughly

${ }^{31}$ De Beauvoir, p. 32. equivalent to how an extended matter lacking all thought, or a non-conscious being, an entity, is conceived; whereas on the second level, the body is conceived of as a conscious being with the ability to think and feel. It should be evident that seen from the perspective of situation, what "body" signifies is not an entity with certain invariant characteristics, but an entity whose features can change since the nature and value of bodies depend upon the social, historical, and economic context within which embodied individuals exist. This is, I think, precisely what de Beauvoir means when she says that "it is not merely as a body, but rather as a body subject to taboos, to laws, that the subject is conscious of himself and attains fulfillment -- it is with reference to certain values that he evaluates himself." 32

Not surprisingly, de Beauvoir's two levels of analyzing the body coincides with the existentialist notion of "being." Jean-Paul Sartre in Being and Nothingness distinguishes between two kinds of "being;" "being-in-itself" (en-soi), and "being-foritself" (pour-soi). It is from this view that de Beauvoir obtains the correlative terms she uses to describe the two levels of human beings as transcendent and immanent: the former signifies the way in which conscious beings exist (the pour-soi); the latter, the way in which non-conscious being, i.e., static objects, exist (the en-soi). Significantly, de Beauvoir's analysis of woman's situation is that she, a transcendent being, is constrained (at least in part) to immanence. Consider the following passage:

\footnotetext{
${ }^{32}$ De Beauvoir, p.36.
} 
As Merleau-Ponty very justly puts it, man is not a natural species: he is a historical idea. Woman is not a completed reality, but rather a becoming, and it is in her becoming that she should be compared with man; that is to say, her possibilities should be defined. What gives rise to much of the debate is the tendency to reduce her to what she has been, to what she is today, in raising the question of her capabilities; for the fact is that capabilities are clearly manifested only when they have been realized - but the fact is also that when we have to do with a being whose nature is transcendent action, we can never close the books. ${ }^{33}$

This passage expresses de Beauvoir's existentialist notion of humans as dynamic, "transcendent" beings, that create themselves through their activities. She combines this view with historicism in considering the meaning of woman's physical characteristics. Thus, despite the fact that she claims woman's body to be weaker, less muscular, less stable, and to possess less lung capacity than a man's, she also argues that when interpreting the female body in her "total situation," such weakness is incomplete and meaningless. This is because it is only within the context of certain social norms and values that differences in lung capacity and muscular mass have any significance. She observes:

${ }^{33}$ De Beauvoir, p. 34. ...'weakness' is revealed as such only in the light of the ends that man proposes, the instruments he has available, and the laws he establishes. ... In brief, the concept of weakness can be defined only with reference to existentialist, economic, and moral considerations. ... Thus, while it is true that in the higher animals the individual existence is asserted more imperiously by the male than by the female, in the human species individual 'possibilities' depend upon the economic and social situation. $^{34}$

The direction of de Beauvoir's analysis of woman's body, then, is toward subjecting the biological statements concerning the body to further historical and material analysis. This is also evident in the fact that de Beauvoir consistently points out in the three initial chapters that woman's biology is incomplete: biological "facts" about the body cannot be interpreted in isolation from the relevant social and economic conditions in relation to which they take on value. For example, she argues that "the value of muscular strength, of the phallus, of the tool can be defined only in a world of values." ${ }^{35}$

De Beauvoir thus establishes a standard for assessing biological claims. Nevertheless, critics still charge her for not following her own standard. ${ }^{36}$ I argue that this is not true, although at first glance, it appears that she does not carry out the promised broad

\footnotetext{
${ }^{34}$ De Beauvoir, pp. 34-35.

${ }^{35}$ De Beauvoir, p. 60.

${ }^{36}$ Evans, p. 68.
} 
analysis of biology in terms of social, economic, and existential factors. As already stated, the chapter on biology contains a host of statements that appear to be neutral, ahistorical, and deterministic. But de Beauvoir also does point out that one cannot make neutral, aperspectival claims about female biology since human physical capacities come to have meaning only when placed in a cultural and historical context. ${ }^{37}$ It is only if we expect de Beauvoir to be making ahistorical claims that we find this is the only possible interpretation. If, on the other hand, we acknowledge that she is not confined to describing the body as a thing, it seems groundless to read her comments as deterministic and masculinist. Instead, de Beauvoir's claim that the female is alienated from her body, for example, has to be interpreted as a description about the body as "situation," not about the body as a "thing." 38

Finally, I would like to return to consider Okeley's criticism about de Beauvoir's "deterministic" account of woman's body. Okeley rightly saw that de Beauvoir formally rejects biological determinism; however, she is seriously mistaken in thinking that a close examination of the details of de Beauvoir's arguments reveals that de Beauvoir contradicts her own claim about the irrelevance and arbitrariness of biological factors. Okeley thinks that of all the female experiences de Beauvoir critically observes, her most controversial account is that of pregnancy and maternity. She says, "Beauvoir's account of motherhood simply repeats the traditional

${ }^{37}$ De Beauvoir, p. xxxiv.

${ }^{38}$ Arp, p. 235. view that women are doomed by their biology: since maternity prevents women from participating in social, public life, women should refrain from becoming mothers, according to Beauvoir." ${ }^{, 39}$ This criticism raises the question whether de Beauvoir is, in fact, taking the position that women's biology necessarily entraps them so as to prevent their attaining equal status in society. ${ }^{40}$

There is, as noted above, the appearance of a conflict in the text insofar as one interprets de Beauvoir's comments ahistorically. Okeley has made much of the fact that de Beauvoir describes the female reproductive capacity as making the woman the "prey to the species," $" 41$ and that she seems to denigrate the usual functions of motherhood. But when de Beauvoir speaks of the female's subordination to the species she is usually thinking of the host of unfavorable conditions under which women, lacking adequate food, health care, and contraceptive control, become pregnant and bear many children to the detriment of their well-being. ${ }^{42}$ In addition, she points out that regarding children as a universal panacea for one's happiness can be naive and harmful. ${ }^{43}$

But having said this, we are not compelled to think that de Beauvoir finds maternity

\footnotetext{
${ }^{39}$ Okeley, p. 97.

${ }^{40}$ It is notable that in making this criticism, Okeley does not refer to the chapter on . motherhood as much as to the material in the first chapter on biology.

${ }^{41}$ De Beauvoir, p. 32.

${ }^{42}$ De Beauvoir, p. 30.

${ }^{43}$ De Beauvoir, p. 521.
} 
always to have negative value for women. De Beauvoir clearly wants to argue that the value of maternity, like pregnancy, depends upon the situation of the woman: the attitude she takes toward these experiences, her social and economic condition, and whether they are freely chosen acts or states imposed upon her. She states:

As for the burdens of maternity, they assume widely varying importance according to the customs of the country: they are crushing if the woman is obliged to undergo frequent pregnancies and if she is compelled to nurse and raise the children without assistance; but if she procreates voluntarily and if society comes to her aid during pregnancy and is concerned with child welfare, the burdens of maternity are light and can be easily offset by suitable adjustments in working conditions. ${ }^{44}$

De Beauvoir finds that, depending on the external conditions, as well as the psychological attitude of the mother, the experience of childbirth is variable among women. Some women, she notes, find childbirth an enriching experience, one that gives them "a sense of creative power; [that] they have accomplished a voluntary and productive task," while for others this experience makes them feel like passive instruments. $^{45}$

\footnotetext{
${ }^{44}$ De Beauvoir, p. 54.

${ }^{45}$ De Beauvoir, p. 506.
}

It should be sufficiently clear that de Beauvoir's biological discussion needs to be interpreted in relation to the historical comments with which she flags such discussion. So, for example, when she claims that woman of all mammals is the one most alienated by her biology, that her body dooms her to immanence, she should be read as intending to say that because woman's social and economic status throughout history has been subordinate to men's, as a consequence her body has been despised and derogated to the level of something shameful. Consequently, de Beauvoir's descriptions of women's biology should be interpreted in light of her further analysis of the roots of women's oppression, noting well that for her these roots are historical and cultural. So conceived, the claim that, for example, woman is "alienated" from her body should be taken as asserting a true proposition about women's bodies as conceived within patriarchal societies; biology thus is also culturally constructed.

\section{Conclusion}

As a summary, I would argue that both the charges of biological determinism and masculinism against Simone de Beauvoir do not have a firm foundation if we take the structure of The Second Sex as central to its interpretation, and if we read her comments about woman's biology in general, and woman's body in particular, in their proper context by following the perspective in her theoretical analysis. I would suggest that once we acknowledge the legitimacy of analyzing the body as situation, we need not find her claims about woman's body as 
deterministic or misogynistic. Instead of reading these comments outside of the social and historical context, I suggest that we consider them as a description of the female body under various patriarchal periods. With this interpretation, the charges mentioned above against de Beauvoir's discussion of the body are not justifiable, though understandable, because it has to be admitted that when de Beauvoir makes the negative-sounding comments, she is not always careful to explain at which level she is discussing, and thus sometimes invites confusion. But if we avoid making rash criticisms, and instead try our best to find ways to reconcile the apparent contradictions, I believe that we can still appreciate The Second Sex and its originality.

\section{References}

Arp, Kristana. 1987. "Beauvoir's Concept of Bodily Alienation". In Critical Essays on Simone de Beauvoir, Edited by Elaine Marks. Boston: G.K. Hall \& Co.

De Beauvoir, Simone. [1952] 1989. The Second Sex. Translated by H.M. Parshley. New York: Vintage.

Ehrmann, Jacques. 1987. "Simone de Beauvoir and the Related Destinies Of Woman and Intellectual". In Critical Essays on Simone de Beauvoir, edited by Elaine Marks. Boston: G.K. Hall \& Co.

Evans Mary. 1987. "Views of Women and Men in the Work of Simone de Beauvoir". In Critical Essays on Simone de Beauvoir, edited by Elaine Marks. Boston: G.K. Hall \& Co.
1985. Simone de Beauvoir.

New York: Tavistock Publications.

Lon, Cline T. 1984. "Simone de

Beauvoir's Woman: Eunuch or Male?". In Ultimate Reality and Meaning: Interdisciplinary Studies in the Philosophy of Understanding. Vol. 11.

O'Brien, Mary. 1981. The Politics of Reproduction. London: Routledge and Kegan Paul.

Okeley, Judith. 1986. Simone de Beauvoir. New York: Pantheon.

Simons, Margaret A. 1995. Feminist Interpretation of Simone de Beauvoir. University Park: Pennsylvania State University Press.

Whitmarsh, Anne. 1981. Simone de Beauvoir and the Limits of Commitment. Cambridge: Cambridge University Press. 